DOI: 10.1515/atd-2015-0039

\title{
Measuring of educational service quality (focused on universities)
}

\section{Ján Kamod'a*}

\begin{abstract}
This paper deals with common problems in the process of education at the university level. It focuses on the quality of education process. The aim of this paper is to determine the principal criteria of the quality measurement of the education service.
\end{abstract}

Key words: education, quality of education, education process, educational service, quality measuring.

\section{Quality of education}

What should be the quality of education like? Unfortunately, nobody knows and nobody tries to find out a current, objective, reliable and actual picture of the education system, the aspects that affect the quality of tuition and education process, or the typical features of a high quality educator, school, faculty etc. If you ask up to 20 people to define the term: "the quality in relation to a faculty", you would most probably receive 20 more or less different answers. Such term has a different meaning for a student, a lecturer, a university graduate, a parent, but also for the government or the parliament.

\subsection{Determination of the term: quality of education process}

Generally, we can say that the following features characterize the education process:

a) Quality as perfection - it is the traditional approach to assess quality with the aim to become the best:

- direct: individually (a student)

- indirect: mediated (by the educational process)

b) Quality as faultlessness.

c) Quality as a capability of purpose - we view education as a utility value, the ability to implement it in life.

* Ján Kamod'a, Dubnica Technological Institute, Dubnica nad Váhom, Slovakia; jankamoda@gmail.com 


\section{Acta Technologica Dubnicae}

volume 1, 2011, issue 1

d) Quality as a readiness and ability to complete tasks and reach the goals executing the mission and orientation of the faculty, meeting the requirements coming from the processes of evaluation and accreditation.

e) Quality as an ability to satisfy a customer - a student.

f) Quality as a financial success - granting the funds only to school that is of a high quality; not to consider the school with enough finances to be of high quality.

g) Quality as a threshold (level) - it is important to be familiar with the levels of lower or higher quality. Therefore, there are set up the "standards of education, criteria, and pedagogical directives."

\subsection{Quality of education - quality of the university}

Universities can be taken as business firms with highly complex and professional offers and fields of activities where we can talk about some principles and goals that confirm their complexity. The dominant characteristics are:

- Freedom of educational policy and research.

- Linking the educational policy and the research.

- Openness for a number of diverse scientific opinions.

- Co-partnership of lecturers and undergraduates.

- Autonomy of the university.

The study at a tertiary level should correspond with the following principles:

- Professional training. When starting a job the graduate should be able to accomplish her/his work duties according to research progress.

- Educational process.

- Subsequent education of university graduates.

As it has been mentioned above the management of the university quality should be focused on education and subsequent education process, science, research, and finally, on the control and organization of the university itself. 


\section{Measuring and assessing the education process quality}

\subsection{Why should we measure?}

There are plenty of reasons why it is necessary to implement the system of quality measurement at the universities, and here we offer some of them. The system of quality should be used, predominantly:
a) for the internal purposes of the faculty;
b) for the pedagogical staff;
c) for improvement of the education process;
d) as the essential material for external inspections;
e) as the basic material for certification;
f) for the use of comparison;
g) for the faculty management;
h) for providing the society with transparent information;
i) for the faculty's human resources management;
j) for achievement, keeping and improving the quality itself.

\subsection{What should we measure?}

We can start with the following model of the quality of education process at a faculty:

Figure 1 Model of the Quality of Education Process

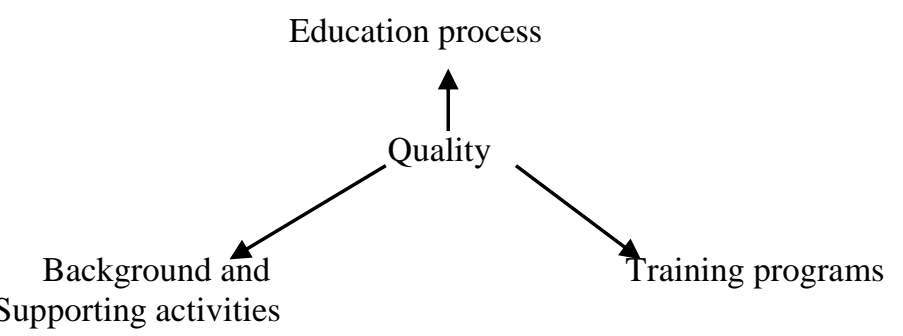

a) Background and supporting activities

- structure of lectures and lecturer's skills;

- material, technical, financial, information background (literature availability, the equipment and the services of study room, library, computer net services...);

- research activities and their connection with the education process;

- feedback of the practice;

- inter-faculty cooperation; 
b) Training programs

- profiles, cooperation with the job market (It is not only the point if a graduate is employed, but if s/he works in her/his field of profession, specialization, a degree $\mathrm{s} / \mathrm{he}$ was awarded, if $\mathrm{s} / \mathrm{he}$ works in a leading position or not...);

- structure and creation of training programs;

- structure and creation of subjects;

- education system, the load of undergraduates;

- flexibility;

c) Education process

- participants of the education process;

\subsection{How should we measure?}

A lot of methodologies providing the evaluation of the education process have been already created. The most widely applied one has been the application of measurable quality indicators and the method of the faculty's virtues and weaknesses analysis, either from the position of a subject, an object or an indirect participant of the educational process. However, none of them does provide a complete picture - the complex information. This can be achieved only by a simultaneous application of both methods. Nowadays, there exists a tendency to move the quality assessment more to the input area, since the output area criterion seems not satisfactory. It should be rather a system that motivates people to think more about themselves, their behavior and the consequences than the system limited to external check out and inspection. It should be the system in which both items - internal self assessment and external examination would be balanced and interconnected (Appendix A).

\subsubsection{Self assessment}

For implementing the self assessment process it is necessary for the faculty to be permanently interested in quality. The purpose is not only to acquire a review of the current situation, but also to create the set of measures, how to keep the achieved level of quality, how to improve it continuously and in the same time how to execute and bring the measures into effect.

The main objectives of the self assessing process are three consequent functions:

1) To stimulate internal quality management and create adequate conditions for it.

2) To prepare the faculty for the external evaluation.

3) To provide the latest information about the faculty's situation for external assessors. 
Procedure of self assessment

- purpose identification;

- process planning;

- data collection;

- classification, analysis, survey;

- elaborating a report;

- expectation of initial situation improvement;

- monitoring.

\subsubsection{External examination}

The principal body here is the evaluating committee - a group of independent external experts appointed by an accreditation committee. The external examination is based on two kinds of information about the faculty:

a) the self-assessing report elaborated by the faculty;

b) the survey made at the faculty.

The committee fulfills two tasks:

A) assessment-advisory

- evaluation of the faculty via quality audit;

- carrying out a written notice with a set of recommendations and suggestions for improvement of the current situation;

B) information-advisory

- arrangement of information about the evaluated faculty;

- setting up the recommendations and suggestions for further steps of supervisory bodies;

The results thus represent the initial information for the accreditation committee.

\section{The analysis of faculties' assessment criteria at the university level}

The accreditation committee usually determines within the scope of its activities the following criteria:

1) The number of staff in the pedagogical process:

a) The full-time employees:

- professors,

- senior lecturers,

- lecturers,

- assistant lecturers, 
- scientific personnel;

b) The part-time employees:

- professors,

- senior lecturers,

- the other employees;

2) Pedagogical process:

a) the total number of undergraduates and postgraduates and the length of a course;

b) the work load of the employees;

3) Scientific and pedagogical qualifications (number of degrees - habilitations and inauguration);

4) Publications of original research;

5) Number of citations;

6) Inventions, discoveries and awarded prizes;

7) The implementation of artistic activities and the research in practice;

8) Allocated grants;

9) Membership in international boards and panels;

10) Membership in national professional and scientific institutions;

11) Finances;

12) The evaluation of the quality of education process:

a) the input profile of an applicant;

b) total and relative number of students;

c) number of students in the grades;

d) the graduates' position in the job market.

Are such criteria really objective enough to obtain a reliable image of a faculty's quality in comparison with other faculties?

The ratio of professors, senior lecturers and other pedagogical staff, and the total number of pedagogical workers

The quality of school is often rated through the number of pedagogical staff employed, as the higher is the number of teachers with academic degrees, the higher is considered the quality of school. But is the quality of accomplished work (the quality of lectures, seminars, workshops...), the ability to attract and motivate students, to apply new achievements, and the ability to present them to students the true reflection of a lecturer's acquired degree?

\section{Number of citations}

However, this criterion seems to contribute to the decision making about quality of education process, there arises another question again: "Can we consider it really 


\section{Acta Technologica Dubnicae}

volume 1, 2011, issue 1

objective, or is it only a part of mutual 'cooperation' of departments, faculties, universities in quoting each other?"

\section{The graduates' position in the job market}

It is understandable that a successful graduate can reflect the faculty's quality, moreover, she/he can have more advantageous position in the job market, but the point is: "Are these aspects really so dominant and crucial in the society? Can job vacancies in the graduate's job market, or if her/his relatives or backing recommendations play a bigger role for getting a job? Or shall we consider good luck and coincidence more than the achieved level of education?"

However, to find the answer to such questions is not difficult. But there is still a question of applying these aspects in the evaluation process of faculty's (school's) quality. Though we have discussed some criteria of the government accreditation boards, we consider their evaluation to be the most vital motivation incentive for retaining the quality of the faculty with the purpose of increasing the effectivity of the quality evaluation. Here are some other ideas to be considered:

1) Creating, establishing a new branch of study (specialization, the change of content of tuition and education policy), merging or splitting the branches (specializations).

2) Cooperation with graduates, contacts, get-together-gatherings, controlling/managing scientific workshops with the graduates.

3) Activities on demand of the supreme organs of executive administration, government agency (elaboration of technical expertise, reviews, suggestions....).

4) Considering the criteria that play role for a student when taking up a university (field of study, specialization).

\section{Questionnaire}

The level of quality is determined by a customer, and a customer is anybody who is being provided some service and the service should be provided on the highest possible level. In our situation a student is a customer, and that is why, she/he has the right to get the highest possible quality of service, which means the best quality education.

The priority of each school should be to know students' expectations, their needs and wishes on the base of reliable sources, but not only via teachers' intuition and experience. All this requires subsequent feedback - surveying the students' attitude to the education process and the school itself, and doing a regular market research. A 
questionnaire method is suitable for such feedback. We applied the method with the purpose to acquire our students' opinions and ideas of the quality of education process (Appendix A).

\section{Evaluation of the questionnaire (Appendix A)}

1. Why did you choose this faculty?

The highest percentage of the asked respondents decided for the answer b) "I considered this faculty to be the best." This choice reveals the students' belief that they have chosen the best quality.

2. Does your study at this faculty meet your expectations?

In this case we could not expect $100 \%$ score, as not all respondents may have passed through all lectures, seminars, so they could not express their opinions.

3. Would you like to have more practical workshops than theoretical lectures included in your study?

The students gave a positive answer, as the professional training from their point of view is not sufficient. A student has not a chance (maybe only a minimal one) to apply her/his theoretical knowledge in practice.

4. Are you satisfied with the methods and quality of lecturers?

Despite the fact that positive answers prevailed, we could often meet with the remarks about missing practical examples in the education process. The ideal situation could be achieved only if there is applied a quality credit system at the faculty that would enable students to choose the lecturers of subjects.

\section{Are you satisfied with the content of lectures and seminars?}

The most respondents again answered "Yes" - $80 \%$ score. Probably because not all lecture rooms are equipped with quality didactic technology.

\section{Do you consider the system of examination rating fair?}

Here the students expressed their disagreement and came up with some sharp critical remarks. The students pointed out at these factors: 


\section{Acta Technologica Dubnicae}

volume 1, 2011, issue 1

- Subjectivity of evaluation from the side of a teacher. Students bear all risks of teacher's current mood.

- Subjective opinion of an examiner, the oral exam is sometimes only a 'lottery', the written exam depends on a person who makes the tasks and who rates them.

- The absence of a lay examiner (assistant).

- Not clear credit system.

- The examiner demands her/his own opinions and examples a student was not presented within the course.

- Sometimes, sitting for an examination is a thoughtless memorizing drill.

\section{Is a student competent to change the training program?}

The answers confirmed our assumptions. There appeared again the bound with a credit system. If there was a well organized system at the faculty, we could expect the answer "Yes". Therefore, it is advisable to introduce a new conception of credit system so that the students have a chance to react on some conceptual issues concerning the faculty's activities.

8. If you had a chance to take up the field of study/specialization again, how would you decide now?

Despite some students' critical remarks to some issues, majority of them would not change their specialization which means they are satisfied with their choice.

9. Are you convinced that the knowledge and experience obtained at the faculty will make you more successful in the job market?

Only half of the students are sure that the knowledge and experience obtained at the faculty will make their application in the job market easier. A student is usually not supplied with much practical experience during her/his course or professional training. By means of the questionnaire we tried to reveal virtues and weaknesses of our faculty and to point at 'the gaps' that our faculty should deal with in the near future (for example, the change of the education system at universities through high quality and in life successfully operating credit system, more thorough preparations of lessons and workshops, reinforcing practical experience and skills ...).

\section{Conclusions}

The purpose of the report was to offer a view on the problem of determining the quality of education process, its measuring and evaluation. This work is based, mainly, 
on theoretical knowledge and data obtained. While handling with the problem we used information obtained from discussions with teachers of the tested faculty, further we used the observation method, we studied the documents (official written documents, book publications, professional periodicals). To sum up the materials we created tables and models. The other testing technique was the questionnaire.

\section{APPENDIX A Questionnaire}

1. Why did you choose this faculty?

a) I had a lot of information about the school: $25.76 \%$

b) I considered it to be the best: $31.82 \%$

c) Good reputation of the faculty: $18.18 \%$

d) Attractive specializations: $10.61 \%$

e) Good recommendations: $13.64 \%$

2. Does your study at this faculty meet your expectations?

Yes: $\mathbf{5 3 . 3 3 \%}$ No: $10 \%$ I don't know: $0 \%$

3. Would you like to have more practical workshops than theoretical lectures included in your study?

Yes: 86.6 \% No: $13.33 \%$

4. Are you satisfied with the methods and quality of lecturers?

a) Yes, the lecturing is OK for me: $7.5 \%$

b) Yes, but there is the lack of:

- computer technology: $13.75 \%$ - examples from practice: $\mathbf{5 3 . 7 5 \%}$

- visual aids: $20 \%$ - others: $1.25 \%$

c) No, the method of lecturing is not OK for me at all: $3.75 \%$

5. Are you satisfied with the content of lectures and seminars?

Yes: $46.67 \%$ No: $8.33 \%$

6. Do you consider the system of examination rating fair?

Yes: $36.67 \% \quad$ No: $\mathbf{6 3 . 3 3 \%}$

7. Is a student competent to change the training program?

Yes: $6.67 \%$ No: $\mathbf{5 1 . 6 7 \%} \quad$ Partially: $28.33 \%$ I don't know: $13.33 \%$

8. If you had a chance to take up the field of study/specialization again, how would you decide now? 
a) I would choose the same specialization at the same university: $56.67 \%$

b) I would choose the same specialization at another university: $8.33 \%$

c) I would choose completely different specialization: $33.33 \%$

d) I would not study: $1.67 \%$

9. Are you convinced that the knowledge and experience obtained at the faculty will make you more successful in the job market?

Yes: $50 \%$ No: $23.33 \%$ I don't know: $26.67 \%$

Sample of Respondents

FACULTY: GRADE: AGE: SEX:

male: $13.33 \%$

female: $86.67 \%$

FOES: $36.66 \% \quad$ I) $48.33 \% \quad 18: 8.33 \%$

FOM: $36.67 \% \quad$ II) $3.33 \% \quad 19: 33.33 \%$

FOT: $26.67 \% \quad$ III) $15 \% \quad 20: 11.67 \%$

IV) $30.5 \% \quad 21: 23.33 \%$

V) $3.33 \% \quad 22: 15 \%$

23: $8.33 \%$

Explanation of abbreviations: Faculty of Economics and Science - FOES, Faculty of Management - FOM, Faculty of Tourism - FOT 
Figure 2 The Basic Model of Quality System at a Faculty

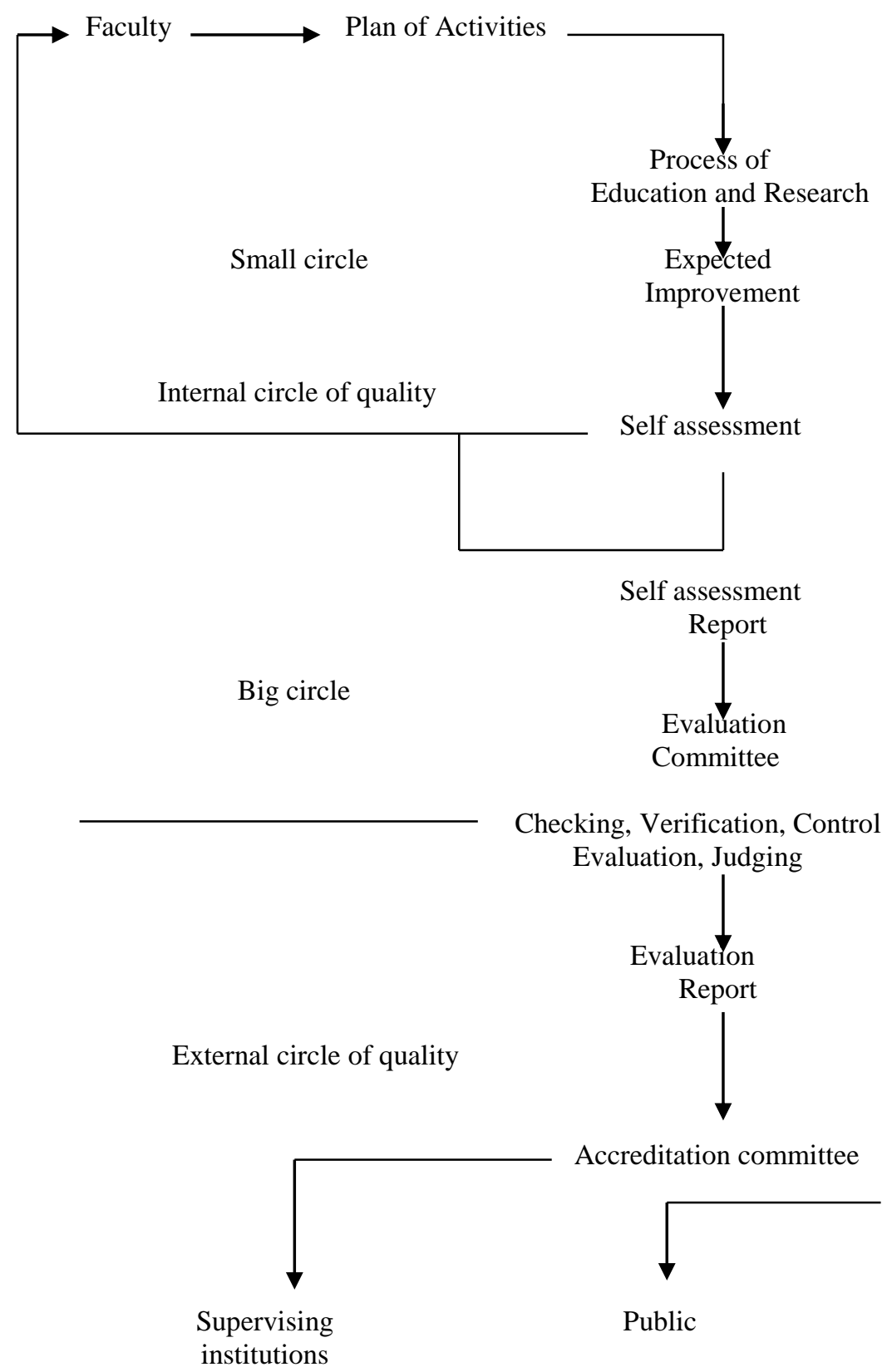




\section{References}

BENČO, J., KAMOĎA, J., HRONEC, Š., SLAČKA,S. 2005. Ekonomika a manažment vzdelávania. Banská Bystrica: Univerzita Mateja Bela, 2005. 300 p.

BENČO, J., KAMOĎA, J.,VEVERKA, L. J. 1998. Základy manažmentu vzdelávania. C̆adca: TYPO, 1998. $121 \mathrm{p}$.

BENČO, J., KAMOĎA, J., NEMEC, J. 2001. Kontrola vo verejnom sektore. Banská Bystrica: Univerzita Mateja Bela, 2001. 108 p.

BENČO, J., KAMOĎA, J., MEČIAR, I. 2004. Verejné služby. Prievidza: ALFA print, 2004. $205 \mathrm{p}$.

DROPPA, M., JANOVJAK, S. A., JANOVJAK, A. Š. 2007. Príručka pre EUmanažéra. Bratislava: LÚČ, 2007. 289 p.

OBDRŽÁLEK, Z. 1994. Škola, školský system, ich organizácia a riadenie. Bratislava: Univerzita Komenského, 1994. 200 p.

ZELINA, M. 1996. Modely riadenia školy. Bratislava: Metodické centrum, 1996. 27 p. 